\title{
TERAPI BERBASIS SEL PUNCA UNTUK STROKE ISKEMIK KRONIK DENGAN MESENCHYMAL STEM CELL ALOGENIK INTRAVENA
}

\author{
Feby Aulia Hasanah*, Nirvana Sabila Nuban \\ Fakultas Kedokteran, Universitas Lampung, Jl. Prof. DR. Ir. Sumatri Brojonegoro No.1, Gedong Meneng, \\ Kec. Rajabasa, Kota Bandar Lampung, Lampung, Indonesia 35145 \\ *febyauliahasanah2902@gmail.com (+6282280049181)
}

\begin{abstract}
ABSTRAK
Mesenchymal Stem Cell atau MSC merupakan sel punca dari sumsum tulang yang bersifat multipotensi untuk berproliferasi menjadi sel-sel neuron dewasa. MSC memiliki karakteristik unik berupa kemampuan neuroprotektif dalam menurunkan inflamasi sehingga dapat menghindari lingkungan toxic yang menyebabkan kematian sel NSC dan dapat mensekresikan berbagai faktor neurotropik untuk mendukung perkembangan sel NSC pada pasien stroke iskemik kronik. Tujuan literature review ini yaitu untuk mengetahui efek terapi terobosan baru berbasis sel punca MSC Alogenik Intravena pada stroke iskemik kronik. Metode yang digunakan adalah metode literature review dari 30 artikel PubMed NCBI, Google Schoolar, dan Elsevier dengan kata kunci "stem cell", mesenchymal stem cell", dan "chronic ischemic stroke" dari tahun 2002 hingga 2019 dan hanya diambil sekitar 19 artikel terpilih. Dari beberapa penelitian yang dilakukan didapatkan hasil uji klinis terkini tahap I dan II bahwa terapi MSC dapat meningkatkan kemampuan fungsional secara positif pada pasien stroke iskemik kronik secara signifikan dengan rata-rata senilai 10 persen dengan minimal efek samping pada rute intravena yang bersumber dari alogenik sumsum tulang. MSC merangsang efek SDF1/CXCR4 sehingga MSC alogenik dapat memodulasi respon inflamasi dan mampu berperan sebagai efek tropic dan neuroprotektif melalui stimulasi neurogenesis, oligodendrogenesis, astrogenesis, remielinisasi, plastisitas aksonal dan angiogenesis. Karena terapi untuk stroke iskemik kronik masih sangat terbatas hingga saat ini, MSC alogenik dapat menjadi kandidat terapi karena pengembangannya yang mudah dan efektif.
\end{abstract}

Kata kunci: alogenik; mesenchymal stem sell; intravena; stroke iskemik kronik; terapi sel punca

\section{STEM CELL BASED THERAPY FOR CHRONIC ISCHEMIC STROKE WITH INTRAVENIC ALLOGENIC MESENCHYMAL STEM CELL}

\begin{abstract}
Mesenchymal Stem Cell or MSC is a multipotential stem cell from bone marrow to proliferate into adult neuron cells. MSCs have unique characteristics in the form of neuroprotective abilities in reducing inflammation so that they can avoid the toxic environment that causes NSC cell death and can secrete various neurotrophic factors to support the development of NSC cells in patients with chronic ischemic stroke. The purpose of this literature review is to determine the effect of a new breakthrough therapy based on Intravenous Allogeneic MSC stem cells on chronic ischemic stroke. The method used is the literature review method from 30 articles PubMed NCBI, Google Scholar, and Elsevier with the keywords "stem cell", mesenchymal stem cell, and "chronic ischemic stroke" since 2002 to 2019 and only about 19 selected articles were taken. From several studies conducted, it was found that the results of the latest clinical trials in stages I and II showed that MSC therapy can significantly improve functional ability in chronic ischemic stroke patients with an average value of 10 percent with minimal side effects on the intravenous route originating from allogeneic bone marrow. MSC stimulates the effect of SDF-1 I CXCR4 so that allogeneic MSCs can modulate inflammatory responses and are able to act as
\end{abstract}


tropic and neuroprotective effects through stimulation of neurogenesis, oligodendrogenesis, astrogenesis, remyelinization, axonal plasticity and angiogenesis. Since therapy for chronic ischemic stroke is still very limited to date, allogeneic MSCs can be potential therapeutic candidates because of their easy and effective development.

Keywords: allogenic; mesenchymal stem cell; intravenous; chronic ischemic stroke; stem cell therapy

\section{PENDAHULUAN}

Stroke adalah gangguan otak fokal ataupun global secara mendadak yang disebabkan oleh gangguan vaskuler dan dapat menyebabkan kematian yang berlangsung selama 24 jam atau lebih (Wittenauer R, 2012). Stroke menyebabkan hambatan aliran darah ke otak sehingga terdapat kematian sel-sel otak. Stroke merupakan penyebab kematian nomor dua di dunia setelah penyakit jantung. Angka kesakitan akibat stroke terus meningkat setiap tahunnya di dunia, data world stroke organization menyatakan terdapat sekitar 13,7 juta kasus stroke baru dengan mortalitas sebesar 5,5 juta jiwa setiap tahunnya (Apriandra R, 2019). Data balitbang kemenkes tahun 2014 menunjukan stroke merupakan penyebab kematian dan penyebab disabilitas tertinggi di Indonesia. Anggaran yang digunakan untuk penyakit stroke juga besar, mencapai Rp2,56 triliun pada tahun 2018, menempati peringkat ketiga setelah penyakit jantung dan kanker. 70\% kasus stroke adalah kasus stroke iskemik yang biasanya disebabkan oleh sumbatan plak atherosclerosis (Kemenkes RI, 2018).

Stroke dapat menyebabkan kematian maupun kecacatan permanen pasca stroke yang tentunya akan menurunkan produktivitas penderita stroke. Disabilitas yang disebabkan stroke cukup tinggi akibat terbatasnya penatalaksanaan stroke yang tersedia terutama stroke iskemik kronik yang masih berupa terapi fisik pasca stroke.
Menurut Wechsler LR tahun 2018, efektifitas terapi fisik juga sangat terbatas sehingga saat ini sangat dibutuhkan inovasi dan terobosan terbaru untuk membantu pasien dengan stroke iskemik kronik.

Salah satu terobosan baru dibidang biologi molekuler saat ini adalah potensi penggunaan teknologi sel punca sebagai terapi stroke iskemik kronik (Marei HE, 2018). Sel punca adalah sel manusia yang masih dapat membelah menjadi berbagai sel endodermal, mesodermal hingga ectodermal (Hsuan YC, 2016) sehingga diharapkan mampu menggantikan sel-sel otak yang rusak akibat stroke.

Terapi sel punca adalah penelitian di bidang sel yang sedang banyak dilakukan karna kemampuannya dalam membentuk jaringan baru sehingga dapat menggantikan sel sel yang rusak pada berbagai penyakit yang menyebabkan kerusakan organ. Terapi sel punca awal untuk stroke iskemik berfokus pada percobaan penggunaan Neural Stem Cells (NSC) endogen. Namun, walaupun NSC bereaksi terhadap stroke iskemik yang ditandai lewat peningkatan proliferasi dan migrasi sel dan berkembang menjadi sel fungsional, hanya 10\%-20\% dari sel sel ini yang bertahan dalam jangka waktu lama (Zhang ZG, 2009). Hal ini menunjukan bahwa NSC tidak efektif dalam pengobatan stroke iskemik dan diperlukan sel lain yang memiliki kemampuan proliferasi baik, dapat meningkatkan perbaikan neural namun 
mampu bertahan dalam jangka waktu lama. Mesenchymal Stem Cell (MSC) adalah sel punca dewasa multipotent yang diambil dari sumsum tulang manusia dan memiliki sifat isolasi dan amplifikasi yang mudah, imunogenisitas rendah, dan fungsi parakrin dan imunomodulator. Berbeda dengan NSC, MSC memiliki karkteristik unik yang memungkinkan kemampuan memperbaiki sel sel otak lebih baik daripada NSC pada stroke iskemik kronik. Karakteristik unik ini adalah kemampuannya menurunkan inflamasi sehingga dapat menghindari lingkungan toxic yang menyebabkan kematian sel NSC dan dapat mensekresikan berbagai faktor neurotropik untuk mendukung perkembangan sel NSC (Moradi F, 2012). Fungsi neurotropik dan neuroprotektif dari mesenchymal stem cell alogenik intravena diharapkan dapat menjadi inovasi terapi pada pasien stroke iskemik kronik.

\section{METODE}

Penulisan ini menggunakan metode studi artikel review. Sumber pustaka yang digunakan yaitu berasal dari penelitian-penelitian dan buku-buku pedoman mengenai terapi berbasis sel punca pada stroke iskemik kronik yang dapat diakses melalui internet di PubMed NCBI, Elseiver, dan Google Scholar dengan kata kunci "stem cell", mesenchymal stem cell", dan "chronic ischemic stroke". Artikel yang didapatkan sekitar 30 artikel yang penulis analisis dari tahun 2002 hingga 2019 dan hanya diambil sekitar 19 artikel terpilih.

\section{HASIL}

Studi eksperimental pada model tikus yang dilakukan oleh Boese (2018) menyebutkan bahwa terapi MSC alogenik dapat memodulasi respon inflamasi dan mampu berperan sebagai efek tropic dan neuroprotektif melalui stimulasi neurogenesis, oligodendrogenesis, astrogenesis, remielinisasi, plastisitas aksonal dan angiogenesis.

Transplantasi MSC intravena di sebuah model tikus yang mengalami iskemia otak juga mengalami peningkatan proliferasi progenitor sel saraf di zona subventrikular (SVZ) sebaik dan sebanyak oligodendrosit dan neurofilamen asli. Bahkan berdasarkan studi, MSC mampu bermigrasi ke jaringan yang rusak untuk kembali membentuk jaringan dewasa yang mirip. Oleh karena itu, setelah kolonisasi, MSC mengekspresikan penanda saraf dan antigen sel endotel dan pelindung saraf. Hal ini dapat terjadi karena MSC merangsang efek SDF-1 (sel derived factor untuk proliferasi sel) / CXCR4 (kemokin yang berfungsi dalam homing sel: progenitor, imun dan hemopoetik serta sel kanker/metastatic/migrasi), yang berfungsi penting di area kerusakan yang mereka serang.

Sebuah penelitian membuktikan bahwa EV yang diisolasi dari MSC melindungi PC12 sel tikus dari kerusakan yang disebabkan oleh glutamat melalui aktivasi jalur PI3K / Akt (Lin SS, 2014). Eksperimen yang dilakukan oleh kelompok lain telah menunjukkan bahwa EV diturunkan dari MSC yang diisolasi dari lemak menyebabkan peningkatan $\mathrm{C} \delta \mathrm{II}$ ekspresi protein kinase dalam garis sel hipokampus tikus dan menginduksi proliferasi saraf (El Bassit G, 2017). Hingga tahun 2019 lalu terdapat 20 clinical trial yang sudah dilakukan untuk mentransplantasikan MSC pada pasien pasca stroke dimana dua diantaranya dikhususkan untuk stroke hemoragik dan 13 studi lainnya dikhususkan pada stroke iskemik. 
Penelitian sejauh ini yang paling jauh dilakukan sudah mencapai tahap 1 dan 2 uji klinis, mengingat jumlah sampel masih kurang dari 100 dan tidak randomized, dosis subterapeutik terapeutik, yang bertujuan untuk menemukan dosis yang tepat dengan efek samping minimal serta mengetahui kerja obat di dalam tubuh (farmakologi). Selain itu penelitian yang dilakukan juga bertujuan untuk mengenal efek samping yang masih terbilang aman (safety) dari kerja MSC pada penderita stroke iskemik (Dabrowska S, 2019).

Penelitian terbaru milik Levy dkk tahun 2019 sudah mencapai tahap uji klinis I dan II pada stroke iskemik kronik. MSC alogenik diinjeksikan kepada 36 subyek penelitian penderita stroke selama enam bulan atau lebih. Dosis pemberian dihitung lewat skala allometric hewan ke manusia dan didapatkan dosis sebesar $1,6 \times 10^{6} \quad \mathrm{MSC} / \mathrm{KgBB}$. MSC yang diberikan diambil dari satu donor manusia dan dikembangkan dalam keadaan rendah oksigen (5\%) sehingga memiliki karakteristik tahan iskemik dan dapat bekerja lebih baik pada stroke iskemik kronik. Penelitian dilakukan kepada 36 subyek dan hanya ditemukan dua efek samping yang diduga berhubungan dengan injeksi intravena MSC alogenik yaitu infeksi saluran kemih dan iritasi di area injeksi. Kedua efek samping tersebut sembuh sepenuhnya.

Folow up pada pasien dilakukan dengan berbagai skala pengukuran fungsional stroke iskemik kronik untuk melihat hasil terapi seperti National Institute of Health Stroke scale, BI, MMSE (MiniMental Status Exam), and Geriatric Depression Scale scores dalam jangka waktu bulan ke-6 dan ke-12. Follow up yang dilakukan mendapatkan hasil berupa peningkatan positif kemampuan fungsional pasien stroke iskemik kronik secara signifikan dengan rata-rata senilai 10 persen.

Sebelum dilakukan pemberian rute intravena, diberikan MSC secara intradermal kepada pasien stroke iskemik kronik pada uji klinis untuk melihat adakah hasil reaksi positif seperti papula eritema. Jika terbilang aman baru ketika itu MSC diberikan secara intravena. Pemberian rute intravena menunjukkan tidak adanya sel rusak baru di jaringan yang rusak atau jumlahnya sangat kecil, dan MSC yang ditransplantasikan dipastikan bertanggung jawab atas peningkatan fungsi pada gangguan yang ditimbulkan stroke tersebut (Levy, 2020). Penelitian tentang MSC telah banyak dilakukan dan teruji aman untuk diberikan pada manusia tanpa memerlukan tambahan immunosupresi (Lalu MM, 2012).

Pada penelitian yang melakukan pengujian dosis, efek samping akibat pengobatan MSC jarang terjadi serta bersifat ringan dan sementara. Pada penilaian serial uji, pengujian laboratorium, elektrokardiogram, dan CT scan dada / perut / panggul tidak ditemukan adanya masalah terkait keamanan pemberian MSC intravena, dengan dropout subjek yang terbatas. Hasil ini konsisten dengan catatan keselamatan yang sangat baik secara keseluruhan mengenai MSC, baik dalam uji klinis subjek manusia di berbagai diagnosis non-serebrovaskular (Devine SM, 2002; Hilfiker A, 2011; Williams AR, 2011) ataupun dalam uji coba stroke (Figueroa FE, 2012; Bang OY, 2005; Honmou O, 2011; Bhasin A, 2011; Hess DC, 2017; Tsang KS, 2017). 


\section{PEMBAHASAN}

Stroke merupakan salah satu penyakit yang menyebabkan mortalitas tertinggi serta morbiditas nomor satu di Indonesia (Kemenkes RI, 2018). Dewasa ini perkembangan terapi stroke mengalami ketertinggalan dengan penyakit jantung. Terapi yang digunakan pada stroke iskemik terbatas pada satu jenis recombinant tissue plasminogen activator (rtPA) dengan golden period yang pendek, yaitu 3,5 sampai 4,5 jam pasca serangan (Schwamm LH, 2013). Sulitnya mengenali gejala stroke membuat pasien terlambat datang ke rumah sakit dan mendapat penanganan, hal ini membuat banyak kasus stroke datang setalah melewati golden period untuk penangan stroke iskemik akut (Ferrarello F, 2011). Pada stroke iskemik kronik terapi yang dapat diberikan sangat terbatas dan masih berupa terapi fisik untuk mendorong perbaikan kemampuan motoric sehingga dibutuhkan terapi kausatif untuk perbaikan kondisi pasien stroke. Menurut Wechsler LR tahun 2018, efektifitas terapi fisik juga sangat terbatas sehingga saat ini sangat dibutuhkan inovasi dan terobosan terbaru untuk membantu pasien dengan stroke iskemik kronik.

Penelitian yang dilakukan oleh CastilloMelendez (2013) membuktikan bahwa MSC memiliki sifat unik pada terapi stroke iskemik kronik. MSC memiliki kemampuan untuk mengurangi inflamasi sambil mengeliminasi kondisi lingkungan yang toxic bagi Neural Stem Cell (NSC). MSC juga mampu mengganti sel yang rusak, dengan melepaskan faktor parakrin secara langsung ke lingkungan. MSC bekerja menyokong fungsi dan keberlangsungan kerja NSC dengan mensekresi beragam faktor neurotropic sehingga selain kerja
MSC itu sendiri bersifat neuroprotektif juga dapat merangsang NSC beregenerasi pada kondisi otak yang telah mengalami iskemik kronik.

Alogenik MSC merupakan MSC yang dikembangkan dari satu sumsum tulang pendonor sehingga memungkinkan aplikasi yang luas dan prosedur yang lebih sederhana tanpa harus mengambil sel punca dari sumsum tulang masingmasing pasien. Pengembangan MSC alogenik dapat dilakukan dengan membuang sedikit sumsum tulang lewat operasi kecil dan kemudian mengisolasi MSC dari jaringan. MSC kemudian dapat dimasukkan ke dalam cawan kultur yang digunakan untuk menumbuhkan sel di laboratorium. Dalam cawan kultur, MSC membelah dengan cepat sehingga, dalam beberapa minggu kultur, sejumlah besar MSC dapat diperoleh (Ullah I, 2015), yang kemudian dapat digunakan untuk terapi.

Alogenik MSC yang dikembangkan dalam keadaan rendah oksigen $(5 \%)$ memiliki karakteristik tahan iskemik lebih baik dari MSC yang dikembangkan dalam keadaan normoxic. Karakteristik tahan iskemiknya menunjukan tingkat proliferasi sel yang lebih tinggi, ekspresi gen sel punca yang lebih baik, serta produksi sitokin dan migrasi sel yang lebih aktif (Vertelov G, 2013).

Karakteristik-karakteristik tersebut membuat MSC alogenik rendah oksigen bekerja lebih optimal pada sel sel otak yang rusak sehingga lebih baik digunakan pada stroke iskemik kronik. Selain transplantasi sumber MSC dari sumsum tulang, MSC juga dapat diisoloasi dari lemak dan diadministrasikan dalam bentuk vesikel ekstraseluler (EVs). EVs merupakan struktur membrane yang mengandung 
lipid, protein, dan asam nukleat dan bersifat khas sesuai dengan asal sel dia berada. Karena ukurannya yang kecil dan kemampuan untuk melewati sawar darah otak, EV sering ditransplantasikan secara sistemik. EV dari MSCs ditransplantasikan ke tikus 24 jam setelah induksi iskemia otak mengaktifkan neurogenesis endogen, meningkatkan jumlah akson, dan meningkatkan fungsi vital hewan. Apalagi setelah administrasi EVs diisolasi dari MSC, pelindung saraf jangka panjang dan modulasi respon imun perifer dapat diamati menjadi lebih aktif. EVs juga memiliki imunogenesitas yang rendah, tidak menyebabkan blockade vascular, dan memiliki kemampuan melewati sawar darah otak. Selain itu EVs juga memiliki sifat imunomodulator, menstimulasi VEGF (angiogenesis) dan neurogenesis, serta kemampuan neuroprotektif yang cukup baik (Savitz SI, 2019).

Saat ini penelitian pada model hewan memiliki dua rute pemberian yaitu pemberian MSC lewat intracerebral dan intravena. Pemberian MSC alogenik lewat intracerebral lebih invasif dan memiliki risiko tinggi efek samping prosedur invasif sehingga pemberian intravena dinilai lebih minim risiko dan lebih mudah diaplikasikan di berbagai kondisi klinis.

\section{SIMPULAN}

Terapi yang dapat diberikan untuk stroke iskemik baik akut maupun kronik saat ini sangat terbatas. Tingginya angka kesakitan dan kematian akibat stroke di Indonesia membutuhkan terapi terobosan baru yang lebih efektif. MSC merupakan sel punca dari sumsum tulang yang bersifat multipotensi untuk berproliferasi menjadi sel-sel neuron dewasa dan mampu menghambat inflamasi sekunder yang terjadi pada pasien pasca serangan stroke serta memodulasi respon imun dan mampu berperan sebagai neuroprotektif. Penelitian saat ini sudah mencapai uji klinis tahap 1 dan 2, sehingga MSC alogenik dapat menjadi kandidat terapi yang efektif serta pemberiannya lewat intravena dapat diaplikasikan dengan mudah di berbagai kondisi klinis membuat MSC alogenik layak untuk digunakan sebagai terapi stroke iskemik kronik.

\section{DAFTAR PUSTAKA}

Apriandra R. 2019. Infodatin: stroke don't be the one. Kemenkes RI.

Bang OY, Lee JS, Lee PH, Lee G. 2005. Autologous mesenchymal stem cell transplantation in stroke patients. Ann Neurol. 57:874882.

Bhasin A, Srivastava MV, Kumaran SS, Mohanty S, Bhatia R, Bose S, et al. 2011. Autologous mesenchymal stem cells in chronic stroke. Cerebrovasc Dis Extra.1:93-104.

Boese AC, Le Q-SE, Pham D, Hamblin MH, Lee J-P. 2018. Neural stem cell therapy for subacute and chronic ischemic stroke. Stem Cell Res Ther. 9(1) :154

Castillo-Melendez M, Yawno T, Jenkin G, Miller SM. 2013. Stem cell therapy to protect and repair the developingbrain : a review of mechanisms of action of cord blood and amnion epithelial derived cell. Front Neurosci. $7: 194$

Dabrowska S, Andrzejewska A, Lukomska B, Janowski M. 2019. A Review: Neuroinflammation as 
a target for treatment of stroke using mesenchymal stem cells and extracellular vesicles. Journal of Neuroinflammation. 16:178

Devine SM. 2002. Mesenchymal stem cells: will they have a role in the clinic? J Cell Biochem Suppl. 38:73-79.

El Bassit G, Patel RS, Carter G, Shibu V, Patel AA, Song S, et al. 2017. MALAT1 in human adipose stem cells modulates survival and alternative splicing of PKC $\mathrm{PII}$ in HT22 cells. Endocrinology. 158(1):183-95.

Ferrarello F, Baccini M, Rinaldi LA, Cavallini MC, Mossello E, Masotti G, et al. 2011. Efficacy of physiotherapy interventions late after stroke: a meta-analysis.J Neurol Neurosurg Psychiatry. 82:136-143.

Figueroa FE, Carrión F, Villanueva S, Khoury M. 2012. Mesenchymal stem cell treatment for autoimmune diseases: a critical review. Biol Res. 45:269-277.

Hess DC, Wechsler LR, Clark WM, Savitz SI, Ford GA, Chiu D, et al. 2017. Safety and efficacy of multipotent adult progenitor cells in acute ischaemic stroke (MASTERS): a randomised, double-blind, placebo-controlled, phase 2 trial. Lancet Neurol. 16:360-368.

Honmou O, Houkin K, Matsunaga T, Niitsu $Y$, Ishiai S, Onodera R, et al. 2011. Intravenous administration of auto serumexpanded autologous mesenchymal stem cells in stroke. Brain. 134(pt 6):1790-1807.
Hsuan YC, Lin CH, Chang CP, Lin MT. 2016. Mesenchymal stem cellbased treatments for stroke, neural trauma, and heat stroke. Brain Behav. Aug 3; 6(10): e00526.

Kemenkes RI. 2018. Kebijakan dan pengendalian stroke di Indonesia.

Lalu MM, McIntyre L, Pugliese C, Fergusson D, Winston BW, Marshall JC, et al. 2012. Canadian Critical Care Trials Group. Safety of cell therapy with mesenchymal stromal cells (SafeCell): a systematic review and metaanalysis of clinical trials. PLoS One. 7:e47559 11

Levy ML, et al. 2019. Phase I/II Study of Safety and Preliminary Efficacy of Intravenous Allogeneic Mesenchymal Stem Cells in Chronic Stroke. AHA Journals. 50(10): 2835-41

Lin SS, Zhu B, Guo Z-K, Huang G-Z, Wang Z, Chen J, et al. 2014. Bone marrow mesenchymal stem cellderived microvesicles protect rat pheochromocytoma PC12 cells from glutamate-induced injury via a PI3K/ Akt dependent pathway. Neurochem Res. 39(5):922-31.

Marei HE, Hasan A, Rizzi R, Althani A, Afifi N, Cenciarelli C, Caceci T, Shuaib A. 2018. Potential of Stem Cell-Based Therapy for Ischemic Stroke. Front Neurol. 6(9):34.

Moradi F, Haji Ghasem Kashani M, Ghorbanian MT, Lashkarbolouki T. 2012. Spontaneous expression of neurotrophic factors and $\mathrm{TH}$, Nurr1, Nestin genes in long-term culture of bone marrow mesenchymal stem cells. Cell J. 13:243-250. 
Savitz SI, Yavagal D, Rappard G, Likosky W, Rutledge N, Graffagnino C, et al. 2019. A phase 2 randomized, shamcontrolled trial of internal carotid artery infusion of autologous bone marrow-derived ALD-401 cells in patients with recent stable ischemic stroke (RECOVERStroke). Circulation. 139:192205.

Schwamm LH, Ali SF, Reeves MJ, Smith EE, Saver JL, Messe S, Bhatt DL, Grau-Sepulveda MV, Peterson ED, Fonarow GC. 2013. Temporal trends in patient characteristics and treatment with intravenous thrombolysis among acute ischemic stroke patients at Get With The Guidelines-Stroke hospitals. Circ Cardiovasc Qual Outcomes. 6:543-549.

Steinberg GK, et al. 2016. Clinical Outcomes of Transplanted Modified Bone Marrow-Derived Mesenchymal Stem Cells in Stroke: A Phase 1/2a Study. Stroke. 47(7): 1817-24

Tsang KS, Ng CPS, Zhu XL, Wong GKC, Lu G, Ahuja AT, et al. 2017. Phase I/II randomized controlled trial of autologous bone marrow-derived mesenchymal stem cell therapy for chronic stroke. World J Stem Cells. 9:133-143.

Ullah I, Subbarao RB, Rho GJ. 2015. Human mesenchymal stem cells current trends and future prospective. Biosci Rep. 35(2):e00191.

Vertelov G, Kharazi L, Muralidhar MG, Sanati G, Tankovich T, Kharazi A. 2013. High targeted migration of human mesenchymal stem cells grown in hypoxia is associated with enhanced activation of RhoA. Stem Cell Res Ther. 4:5. 12

Vu Q, Xie K, Eckert M, Zhao W, Cramer SC. 2014. Meta-analysis of preclinical studies of mesenchymal stromal cells for ischemic stroke. Neurology. 82:1277-86.

Wechsler LR, Bates D, Stroemer P, Zwilling YSA, Aizman I. 2018. Cell Therapy for Chronic Stroke. AHA Journals. 5(49): 1066-74.

Williams AR, Hare JM. 2011. Mesenchymal stem cells: biology, pathophysiology, translational findings, and therapeutic implications for cardiac disease. Circ Res. 109:923-940.

Wittenauer R, Smith L. 2012. Ischaemic and Haemorrhagic Stroke. WHO. 6: 3-9.

Zhang ZG, Chopp M. 2009. Neurorestorative therapies for stroke: underlying mechanisms and translation to the clinic. Lancet Neurol. 8:491-500. 